Joanna Roś

\title{
ŚMIERĆ: \\ NADANIE SENSU CZY ODEBRANIE ZNACZENIA? ANALIZA FILOZOFICZNA DRAMATU PRZY DRZWIACH ZAMKNIECTYCH JEANA-PAULA SARTRE'A
}

Inez, bohaterka dramatu Sartre'a pt. Przy drzwiach zamkniętych z perspektywy piekła spogląda na ziemię, na żyjących ludzi, przebywających w jej dawnym pokoju. Mówi zaniepokojona: „dopiero teraz n a praw dę umarłam". Stwierdzenie to uwyraźnia nam Sartre'owskie rozróżnienie dwóch rodzajów śmierci, ukazanych w Bycie i nicości: śmierci „na-wpół” i śmierci absolutnej, charakteryzującej się brakiem pamięci o zmarłym. Tego ostatniego rodzaju śmierci doświadcza Inez, gdy widzi obcych w pomieszczeniu, które ją określało - niezainteresowanych kim była zmarła właścicielka pokoju. Przestrzenie, które świadczyły o Inez za życia, są teraz miejscami dla innych ludzi i już nie stanowią symboli pamięci o niej. Śmierć odebrała Inez przywilej posiadania. Kobieta rozumie to, czemu daje wyraz, stwierdzając: „Nie ma już nic twojego na ziemi”2 wobec Stelli, przebywającej z nią w piekle. Stella natomiast jest oburzona, widząc swoją ziemską miłość w towarzystwie młodej kobiety, będącej niegdyś jej przyjaciółką. Wspomnieniami o kochanku, w których podkreśla, że do niej należał, wciąż pragnie „posiadania”, jednak śmierć odebrała znaczenie jej ziemskiemu

${ }^{1}$ J.P. Sartre, Za zamkniętymi drzwiami, [w:] Dramaty, przeł. J. Kott, PIW, Warszawa 1956, s. 153.

${ }^{2}$ Tamże, s. 156. 
czasowi i tylko pamięć żyjących o niej powoduje, że jest w specyficzny sposób „na wpół obecna”. Stella zwraca się do żyjącego kochanka, Piotra, aby ten nie przestawał o niej myśleć, bronił ją przed oskarżeniami żyjącej przyjaciółki, przed tym, co stanie się z pamięcią o niej samej ${ }^{3}$.

Jak pisze Sartre, kiedy „żyjące” staje się „martwe”, pamięć drugiego człowieka, Innego, jest przeszkodą, chroniącą przed utratą więzi z teraźniejszością przez „martwe”. „Właściwością «martwego życia» jest tedy to,

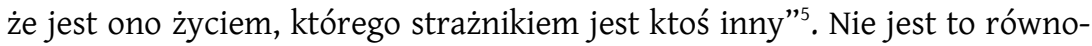
znaczne z sytuacją, gdy ktoś „zachowujący życie” przechowuje w pamięci tego, kto umiera. Nie jest to także podobne do jakiegoś rodzaju przywrócenia życia. Inny ustosunkowuje się do zmarłego na wiele sposobów: rodzina może „przywracać” go za pomocą wspomnień, książki historyczne „przypominać o nim” własną treścią, ale wciąż istnieje możliwość „życia popadłego w zapomnienie". Bycie zapomnianym i bycie pamiętanym zależą od pewnych postaw innych ludzi, którzy „zostają na ziemi” i zależą bezpośrednio od decyzji przez nich podjętych względem umarłego. Żyjący wybierają postawę wobec zmarłych i nie jest możliwe, aby takie ustosunkowanie nie wystąpiło. Faktyczność jest tym, przez co „Inny” byt-dla-siebie staje się odpowiedzialny za umarłego. Według filozofa, żyjący zobowiązani są do decydowania o losie umarłych, szczególnie wtedy, gdy chodzi o ich bliskich $^{6}$. Sartre w Bycie i nicości podaje odpowiadający temu przykład syna, który podejmuje się przejęcia ojcowskiej firmy, oraz ucznia, biorącego odpowiedzialność za szkołę, którą prowadził jego zmarły nauczyciel ${ }^{7}$.

Analogię odnajduję $\mathrm{w}$ historii Orestesa, przedstawionej w dramacie Muchy. Orestes pragnie przejąc ojcowski tron, aby zadecydować o losach państwa, rządzonego niegdyś przez ojca. Uwyraźnia się tu, jak wykazuje Sartre, niepodważalna różnica i niesprowadzalność do siebie życia i śmierci. Życie charakteryzuje się niewyczerpującą się zdolnością analizowania podejmowanych przez człowieka wyborów, możliwości ich pochwały czy

${ }^{3}$ Zob. tamże, s. 157.

${ }^{4}$ Zob. tenże, Byt $i$ nicość, przeł. J. Kiełbasa, P. Mróz, Wydawnictwo Zielona Sowa, Kraków 2007.

${ }^{5}$ Tamże, s. 664.

${ }^{6}$ Zob. tamże, s. 666.

${ }^{7}$ Zob. tamże. 
też krytyki, dzięki której żyjący może wciąż zmieniać samego siebie. Życie zmarłego już nigdy się nie zmieni, wszystko, co do niego należało, już się dokonało, a więc samo już się nie zmienia, a jedynie podlega zmianom. Nie można jednak mówić - twierdzi filozof - aby samo działało w kierunku dokonania zmiany i aby przysługiwała mu jakakolwiek odpowiedzialność za zmiany, które żyjący w nim przeprowadzająa.

Za życia odpowiedzialność za decyzje i nadanie im sensu jest zależna od samego człowieka, który się ich podejmuje. Śmierć odmienia tę sytuację, ponieważ „być umarłym to być wydanym na pastwę tym, którzy żyją" Garcin także odczuwa niemożliwość pośmiertnego wpływu na myśli innych. Przyznaje, że umierając zostawił swoje życie w rękach innych. Stan ten nazywa „staniem się własnością publiczną”, „oddaniem życia w ręce żyjących" ${ }^{10}$. Wie, że śmierć decyduje o tym, co inni zakwalifikują jako jego istotę, czy czyny, których się podejmował, zostaną zakwalifikowane jako tchórzliwe czy też bohaterskie, a ci, którzy zostali na ziemi, ocenią, kim był. Za życia mógł wymykać się temu, kim był dla innego, ponieważ sam sprawiał, że był tym, kim był. Sartre śmierć przyrównuje do gry, gdzie wygranym jest zawsze pozostający przy życiu, a przegraną umarłego staje się skazanie na istnienie wyłącznie dzięki innemu i od niego uzależnione ${ }^{11}$. To właśnie śmierć Garcina rozstrzyga: czy znaczenie, jakie nadawał sobie za życia, utrzyma się po niej. Jednak śmierć skazująca umarłego na nieograniczone znaczenia, nabierające cech przedmiotowych, jest uzależniona od żyjących i tego, które z tych cech postanowią przypisać umarłemu.

W ten sposób dochodzimy do Sartre'owskiej tezy, że śmierć nie zawiera ontologicznej struktury bytu-dla-siebie, ponieważ nie należy do możliwości człowieka. Człowiek „nie może jej rzutować na siebie tak, jak inną ze swoich możliwości"12. Życie człowieka staje się ludzkim losem za sprawą innego. Ze względu na niego śmierć ludzka nie jest równoznaczna ze śmiercią wszelkiej ludzkiej świadomości, nie równa się unicestwieniu świata, a jedynie unicestwieniu podmiotu człowieka w obrębie świata. Moment śmierci

\footnotetext{
${ }^{8}$ Zob. tamże.

9 Tenże, Za zamkniętymi..., dz. cyt., s. 167.

${ }^{10}$ Tamże, s. 166-167.

${ }^{11}$ Zob. tenże, Byt..., dz. cyt., s. 667.

${ }^{12}$ Tamże, s. 669.
} 
jest równie abstrakcyjny, jak ona sama. Garcin mówi, że śmierć odebrała mu możliwość dokonania własnych czynów, a więc zauważa brak „zawieszenia w powietrzu"13, o którym na kartach Bytu i nicości wspomina Sartre. Śmierć nigdy nie pojawia się we właściwym czasie, jest zawsze czymś, przychodzącym za wcześnie i za późno ${ }^{14}$. Pozostawia życie skończone i pozbawione znaczenia, nad którym inni, żyjący, dokonują rachunku.

Dobrze wyrażają to słowa Inez wypowiadane w jednej z ostatnich scen Przy drzwiach zamkniętych w odpowiedzi na wściekły atak Stelli, która usiłowała ją ponownie zabić: „Wiesz przecież, że jestem umarła. [...] Umarła! Umarła! Umarła! Ani nóż, ani trucizna, ani sznur. To już się stało"15. Tę kwestię, która wieńczy sztukę, można zinterpretować na dwa sposoby. Z jednej strony „stał się już” fakt nieuchronnej śmierci, ze świadomością której żyje każdy człowiek i która jest wyłącznie kwestią jego własnej świadomości. $\mathrm{Z}$ drugiej strony, śmierć człowieka stanowi taki sam fakt, jak jego narodziny. Śmierć bowiem - według Sartre'a - stanowi odsłonięcie absurdalności wszelkich pragnień, pożądań, wszystkiego, co nazwać można oczekiwaniem. Jest odsłonięciem absurdalności samego oczekiwania na nią ${ }^{16}$. Filozof zdecydowanie przeczy jakoby śmierć była zdeterminowaniem istnienia, jego zarysem i określeniem. Opowiadając się za wizją świata pozbawioną Boga, kierującego ludzkimi losami, który w swojej łasce nie tylko powołuje do życia, ale także je odbiera, Sartre nie odnajduje miejsca dla śmierci w obszarze tego, co nadaje sens. Albowiem sens człowieka może wypływać wyłącznie z jego podmiotowości, a więc być tym, co on sam ustanowi. Filozof pisze, że śmierć, która nie należy do władz ludzkiej wolności, a więc nie operujemy nią dowolnie, w zależności od potrzeb i decyzji, prezentuje się jako czysta absurdalność i tak też ukazuje działania człowieka, pozbawiając jego życie jakiegokolwiek znaczenia ${ }^{17}$.

Człowiekowi stale doskwiera uczucie nieokreśloności, ponieważ przeczuwa on, że śmierć odbierze mu sens, nie stając się żadnego rodzaju rozwiązaniem jego życiowych problemów. Człowiek, który wie, że musi

\footnotetext{
${ }^{13}$ Tamże, s. 666.

${ }^{14}$ Zob. tenże, Za zamkniętymi..., dz. cyt., s. 173.

${ }^{15}$ Tamże, s. 176.

${ }^{16}$ Zob. tenże, Byt..., dz. cyt., s. 655.

${ }^{17}$ Zob. tamże, s. 660.
} 
umrzeć, to według Sartre'a człowiek, którego problemy nie będą rozwiązane, który nie uchwyci nigdy znaczenia swoich problemów, a on sam w nich zanurzony pozostanie istotą nieokreśloną ${ }^{18}$. W związku z przedstawieniem wniosków o śmierci odbierającej wszelkie znaczenie, autor Bytu i nicości przeczuwa ryzyko krytyki jakoby miał nawoływać do aktów samobójczych bądź je usprawiedliwiać. Przecież, można by powiedzieć, człowiek, mający świadomość, że problemy jego są nierozwiązywalne, a niewiadoma, jaką stanowią, ostatecznie skończy się śmiercią, nie powinien obawiać się rezygnacji z doczekania się jej i samemu ukrócić swój abstrakcyjny żywot. Wydawałoby się, że powinien sam, jako niepodległy żadnej wyższej od siebie instancji, zdecydować o momencie kresu swojego życia.

W sztuce Przy drzwiach zamkniętych odnajdujemy dwa wyraźne motywy samobójstwa, dotyczące dwóch postaci dramatu - Inez i Stelli. Pierwsza z nich „to jest historia o umarłych"19. Inez, darząca zakazaną miłością przyjaciółkę Florę, opowiada o decyzji samobójstwa podjętej przez jej ukochaną. Żyjąca w emocjonalnym trójkącie z Inez i swoim kuzynem ostatecznie decyduje związać się z Inez. Nie mogąc jednak podnieść się po niespodziewanej, tragicznej śmierci kuzyna, decyduje się na samobójstwo i zabija siebie oraz Inez, „odkręcając po cichu kurek od gazu”20. Widzimy, że samobójcza śmierć Flory, gdzie Inez ginie jako ofiara jej decyzji, nie sprawia, że problemy Inez rozwiązują się, nie następuje tu żadne usprawiedliwienie czy rozgrzeszenie uczynków. Sama Inez przyznaje, że nawet po śmierci czuje się złą osobą i wciąż „musi czuć jak inni cierpią" ${ }^{21}$. Stella natomiast, wspominając samobójczą śmierć kochanka, wykrzykuje: „Jestem podła”22, ponieważ wciąż dręczy ją poczucie winy.

W Bycie i nicości Sartre przestawia swój pogląd na istotę samobójstwa. Uważa, że samobójstwo nie jest czymś w rodzaju życiowego celu czy kresu życia, który ma swoje źródło w tym, kto je popełnia. W przeciwieństwie do samobójstwa, wszystko, co należy do ludzkiego życia, musi zakończyć się nadaniem znaczenia, które dokonuje się dzięki przyszłości. Samobójstwo

\footnotetext{
${ }^{18}$ Zob. tamże, s. 662.

${ }^{19}$ Tenże, Za zamkniętymi..., dz. cyt., s. 146.

${ }^{20}$ Tamże, s. 148.

${ }^{21}$ Tamże, s. 147.

${ }^{22}$ Tamże, s. 151.
} 
jednak, jako „ostatni akt życia”23, nie wyznacza dla siebie istnienia jakiejś przyszłości, nadającej ów sens, i tym samym pozostaje na zawsze nieokreślone. Nieokreślone równie jak problemy, z którymi człowiek umiera śmiercią naturalną. Jednakże o ile za życia człowiek jest w stanie rozwiązać niektóre własne problemy, poprzez decyzje, podejmowane w tym celu, o tyle samobójstwo jest postawieniem ich wszystkich w stan absurdalności absolutnej, albowiem wyklucza wszystkie późniejsze projekty.

${ }^{23}$ Tenże, Byt..., dz. cyt., s. 662. 